\title{
Financing Quality in Mexican State Public Universities
}

\section{Ocegueda, Marco Tulio; Moctezuma, Patricia and Mungaray, Alejandro*}

School of Economics and International Relations, Autonomous University of Baja California, Calzada Universidad 14418 Parque Industrial Internacional Tijuana, Tijuana B.C. 22390, México.

\begin{abstract}
The policy of financing with extraordinary biding subsidies as implemented by the Secretariat of Public Education (SEP) for Public State Universities (UPES) between 2001 and 2013 is analyzed. The results indicate that, with some regional differences, this form of distributing of Public resources has been effective by rewarding the Institutional Progress of those UPES in matters of quality, impacting their institutional processes of consolidation in a positive way, contributing to social equity through more and better educational spaces and diminishing the performance gaps between them during the period.
\end{abstract}

Keywords: The Integral Program of Institutional Strengthening (PIFI); Public State Universities (UPES); equity and quality; higher education.

\footnotetext{
* The authors are grateful for the comments and observations of the reviewers, who in many ways helped to improve the present work.
} 


\section{Introduction}

The objective of this work is to analyze the impact of the financing policy of the SEP in the institutional progress of those UPES between 2001 and 2013; its incidence in the improvement of its educational quality and equity; and to contribute to the debate regarding the concerns of the country's UPES. To do that, a model that relates the bidding subsidy received by the UPES with their performance indicators are estimated and econometric exercise is performed. This allows an evaluation of the effectiveness of the SEP's policy in order to promote and motivate best institutional practices. The results achieved allow upholding that the model for assigning them has been successful in the attainment of its proposed objectives.

In the second part of this work the problem of financing higher education in Mexico is discussed, the different stages that have been traversed in their developmental process, as well as the different policies that the State has put in place. After that the methodology is presented and the handling of the information that has been used is described. In the fourth part the most important relationships between the strategic variables and the performance patterns, are analyzed for the IES's associated with extraordinary public financing carried out during the period being analyzed. Finally a reflection about the main findings arrived at during this herein research is made.

\section{The discussion over financing public higher education in Mexico}

The higher learning system (SES) in Mexico, between 1970 and 1982 had a phase of rapid expansion in its enrollment supported by a greater allocation of resources. This process allowed greater opportunities for access to a growing and diverse population, but at the same time characterized by an absence of policies that would give coherence to the educational system as a whole and for its negative impact to the quality of the majority of the educational programs of public universities (Muñoz 1988; Bruner 1994; Arizmendi and Mungaray 1994; Rodríguez 1995). Therefore a public debate was started regarding whether it was pertinent to continue supporting this sector within a context characterized by growing social need and scarcer economic resources. During the decade of the eighties, the recurrent economic crises in Mexico generated important budgetary adjustments to the SES that inhibited the growth from the previous years, and increases the gubermental regulation and evaluation of the system.

As of the decade of the nineties one of the most prolonged and consistent efforts in the policies to reform higher education began. The internal and external efficiency of the institutions to obtain additional public funds, measured by the attainment of their education objectives and by the capability of their graduates to place themselves in the job market, became the central concerns of those very same IES's (Sorensen and Torfing 2011; O'Leary and Vij 2012). The contribution of those graduates to social mobility, the improvement of 
income distribution and the social cost of providing finance to this sector, became topics of public debate (Mungaray and López 1996; Márquez 1999; Aguilar y Castañeda 2009). At the end of the nineties, through gradual changes there was an advance in both the organization of the SES and new institutional models; in the diversification of available programs; and in a growing connection between the educational, research, and private sector activities (Valenti and Mungaray 1997; De Vries 2002). Nonetheless, in a general manner, three fundamental challenges were being acknowledged for developing the SES: 1) To offer educational programs with quality and usefulness, accessible to all social groups; 2) Implement a new model for allocating extraordinary subsidies that would recognize and stimulate the educational quality; and 3) Achieve consensus for a State policy in matters of financing so as to promote the development of the sector for the long term (ANUIES 2002).

\section{Methodology and Data}

With the purpose of evaluating the allocation model of extraordinary subsidies that were under bid between 2001 and 2013, one econometric exercise was carried out. This measures the effectiveness of the financing policies to timely reward the universities' progress in the subjects of educational quality and equity. If the resources up for bidding are distributed favoring the institutions that show the greatest degree of progress in the performance indicators, it is an indication that the model has been functional and successful. Therefore

$$
\mathrm{Y}=\beta_{0}+\beta_{1} \mathrm{X}_{1}+, \ldots,+\beta_{\mathrm{n}} \mathrm{X}_{\mathrm{n}}+\mathrm{u}_{\mathrm{i}}
$$

where:

- Y represents the proportion of PIFI resources delivered to the UPE's in relation to the national total for each of the years considered (2002 to 2013).

- $\beta_{1} \mathbf{X}_{1}+, \ldots,+\beta_{n} X_{n}$ include the information of the institutional performance indicators of the UPES's (see Table 1).

- $\quad \mathbf{u}_{\mathbf{i}}$ is the stochastic term of the model. 
Table 1. Quality and equity variables for measuring the institutional performance of UPE's.

\begin{tabular}{|c|c|c|}
\hline Variable & $\begin{array}{l}\text { Academic } \\
\text { competitiveness } \\
\text { indicators }\end{array}$ & Definition \\
\hline Quality & TPLEC & $\begin{array}{l}\text { Total number of quality bachellor programs of each UPE/ Total number of } \\
\text { bachellor programs that are subject to evaluation. }\end{array}$ \\
\hline Equity & TMLEC & $\begin{array}{l}\text { Total enrollment for the UPE quality bachellor/ Total enrollment for } \\
\text { bachellor that are subject to evaluation. }\end{array}$ \\
\hline Quality & TPNPC & $\begin{array}{l}\text { Total number of programs in the PNPC (International competence, } \\
\text { consolidated, in development and of recent creation) of each UPE/Total } \\
\text { number of programs in the PNPC of the UPE's. }\end{array}$ \\
\hline Quality & ET & $\begin{array}{l}\text { Terminal efficiency (this information was taken as it appears in the SES } \\
\text { electronic website (SEP, 2006b). }\end{array}$ \\
\hline Quality & TCAC & $\begin{array}{l}\text { Total number of consolidated academic bodies in the universities/ Total } \\
\text { number of academic bodies (Consolidated, in consolidation and under } \\
\text { formation). }\end{array}$ \\
\hline Quality & TPROMEP & $\begin{array}{l}\text { PTC number with a desirable PROMEP profile of each state's study } \\
\text { institution / PTC total }\end{array}$ \\
\hline Quality & SNI & PTC number that belongs to the SNI / PTC total \\
\hline
\end{tabular}

\section{Analysis and discussion of the results}

The allocation of the extraordinary subsidies through the PIFI as the instrument for evaluating and rewarding the progress of institutions of the UPES between 2002 and 2013, indicated in the first place that the proposed models show the positive signs that were expected of the coefficient of the explanatory variables (see Table 2). 
Ocegueda, M. T.; Moctezuma, P.; Mungaray, A.

Table 2. Econometric results of the PIFI allocation model on the basis of performance by the UPES 2002-2013.

\begin{tabular}{|c|c|c|c|c|c|c|c|c|c|c|c|}
\hline \multirow[b]{2}{*}{$\begin{array}{l}\mathrm{N} \\
\mathrm{O}\end{array}$} & \multirow[b]{2}{*}{$\begin{array}{l}\text { Dependen } \\
\mathrm{t} \text { variable }\end{array}$} & \multirow[b]{2}{*}{ Constant } & \multicolumn{4}{|c|}{ Independent variables } & \multicolumn{5}{|c|}{ Statistic } \\
\hline & & & & & & & $\begin{array}{c}\mathrm{R}^{2} \text { Adju } \\
\text { sted }\end{array}$ & $\mathrm{F}$ & $\mathrm{n}$ & $A$ & \\
\hline 1 & Pifi $_{2002}$ & $\mathrm{C}$ & TPLEC $_{20}$ & TDOC $_{2002}$ & $\mathrm{ET}_{97 \_02}$ & & 0.4808 & 11.19 & 3 & $5 \%$ & 1 \\
\hline & $\mathrm{t}$ & $\begin{array}{c}0.01568 \\
4.655\end{array}$ & $\begin{array}{c}02 \\
0.0268 \\
3.023\end{array}$ & $\begin{array}{c}0.0274 \\
1.557\end{array}$ & $\begin{array}{c}0.0080 \\
1.100\end{array}$ & & & 0 & 4 & & $\%$ \\
\hline 2 & $\mathrm{Pifi}_{2003}$ & $\mathrm{C}$ & TPLEC $_{20}$ & $\mathrm{TCAC}_{2003}$ & & & 0.5133 & 19.58 & 3 & $5 \%$ & 1 \\
\hline & $\mathrm{t}$ & $\begin{array}{c}0.0191 \\
8.203\end{array}$ & $\begin{array}{c}03 \\
0.0408 \\
4.879\end{array}$ & $\begin{array}{c}0.1211 \\
1.720\end{array}$ & & & & & & & \\
\hline 3 & $\mathrm{Pifi}_{2004}$ & $\mathrm{C}$ & TMLEC & $\mathrm{TSNI}_{2004}$ & & & 0.6213 & 28.07 & 3 & $5 \%$ & 1 \\
\hline & $\mathrm{t}$ & $\begin{array}{c}0.0058 \\
1.440\end{array}$ & $\begin{array}{c}2004 \\
0.0452 \\
6.401\end{array}$ & $\begin{array}{c}0.0627 \\
2.157\end{array}$ & & & & 2 & 4 & & $\%$ \\
\hline 4 & $\operatorname{Pifi}_{2005}$ & $\mathrm{C}$ & TMLEC & $\mathrm{TPROMEP}_{2}$ & & & 0.4765 & 16.01 & 3 & $5 \%$ & 1 \\
\hline & $\mathrm{t}$ & $\begin{array}{c}0.0064 \\
1.033\end{array}$ & $\begin{array}{c}2005 \\
0.0418 \\
4.723\end{array}$ & $\begin{array}{c}005 \\
0.0304 \\
1.142\end{array}$ & & & & & & & \\
\hline 5 & $\mathrm{Pifi}_{2006}$ & $\mathrm{C}$ & TMLEC & $\mathrm{TCAC}_{2006}$ & & & 0.5721 & 23.05 & 3 & $5 \%$ & 1 \\
\hline & $\mathrm{t}$ & $\begin{array}{c}-0.0074 \\
-1.147\end{array}$ & $\begin{array}{c}2006 \\
0.0442 \\
4.765\end{array}$ & $\begin{array}{c}0.1453 \\
3.305\end{array}$ & & & & 8 & 4 & & $\%$ \\
\hline 6 & $\operatorname{Pifi}_{2007}$ & $\mathrm{C}$ & TMLEC & $\mathrm{TCAC}_{2007}$ & $\mathrm{TPNPC}_{20}$ & & 0.8295 & 54.49 & 3 & $5 \%$ & 1 \\
\hline & $\mathrm{t}$ & $\begin{array}{l}-0.0152 \\
-3.217\end{array}$ & $\begin{array}{c}2007 \\
0.0402 \\
5.964\end{array}$ & $\begin{array}{c}0.0604 \\
3.284\end{array}$ & $\begin{array}{c}07 \\
0.3327 \\
5.819\end{array}$ & & & 7 & 4 & & $\%$ \\
\hline 7 & $\mathrm{Pifi}_{2008}$ & $\mathrm{C}$ & $\begin{array}{c}\text { TMLEC } \\
2007\end{array}$ & TCAC $_{2007}$ & $\begin{array}{c}\text { TPNPC }_{20} \\
07\end{array}$ & & 0.8345 & $\begin{array}{c}20.85 \\
6\end{array}$ & $\begin{array}{l}3 \\
4\end{array}$ & $5 \%$ & $\begin{array}{l}1 \\
\%\end{array}$ \\
\hline & $\mathrm{t}$ & $\begin{array}{l}-0.0150 \\
-3.259\end{array}$ & $\begin{array}{c}0.0402 \\
6.104\end{array}$ & $\begin{array}{c}0.0604 \\
3.365\end{array}$ & $\begin{array}{c}0.3278 \\
5.872\end{array}$ & & & & & & \\
\hline 8 & $\mathrm{Pifi}_{2009}$ & $\mathrm{C}$ & TMLEC & $\mathrm{TCAC}_{2007}$ & $\mathrm{TPNPC}_{20}$ & & 0.8571 & 66.99 & 3 & $5 \%$ & 1 \\
\hline & $\mathrm{t}$ & $\begin{array}{c}-0.0121 \\
-3.058\end{array}$ & $\begin{array}{c}2007 \\
0.0376 \\
6.657\end{array}$ & $\begin{array}{c}0.0540 \\
3.506\end{array}$ & $\begin{array}{c}07 \\
0.3120 \\
6.510\end{array}$ & & & 0 & 4 & & $\%$ \\
\hline 9 & $\operatorname{Pifi}_{2010}$ & $\mathrm{C}$ & TMLEC & TCAC $_{2008}$ & $\mathrm{TPNPC}_{20}$ & $\mathrm{TPOSG}_{2}$ & 0.8528 & $\begin{array}{c}48.80 \\
6\end{array}$ & $\begin{array}{l}3 \\
4\end{array}$ & $5 \%$ & $\begin{array}{l}1 \\
\%\end{array}$ \\
\hline & $\mathrm{t}$ & $\begin{array}{c}-0.0474 \\
-3.156\end{array}$ & $\begin{array}{c}0.0405 \\
6.665\end{array}$ & $\begin{array}{c}0.0265 \\
2.752\end{array}$ & $\begin{array}{c}0.2817 \\
5.665\end{array}$ & $\begin{array}{c}0.0399 \\
2.095\end{array}$ & & & & & \\
\hline 1 & Pifi $_{2011}$ & $\mathrm{C}$ & TMLEC & TCAC $_{2009}$ & $\mathrm{TPNPC}_{20}$ & $\mathrm{TPOSG}_{2}$ & 0.8120 & 36.63 & 3 & $5 \%$ & 1 \\
\hline 0 & $\mathrm{t}$ & $\begin{array}{c}-0.0368 \\
-2.196\end{array}$ & $\begin{array}{c}2009 \\
0.0497 \\
5.360\end{array}$ & $\begin{array}{c}0.0459 \\
3.193\end{array}$ & $\begin{array}{c}09 \\
0.2751 \\
5.720\end{array}$ & $\begin{array}{c}009 \\
0.0107 \\
0.541\end{array}$ & & 1 & 4 & & $\%$ \\
\hline 1 & $\operatorname{Pifi}_{2012}$ & $\mathrm{C}$ & TMLEC & TCAC $_{2010}$ & $\mathrm{TPNPC}_{20}$ & $\mathrm{TPOSG}_{2}$ & 0.7160 & 21.79 & 3 & $5 \%$ & 1 \\
\hline 1 & $\mathrm{t}$ & $\begin{array}{c}-0.0468 \\
-1.927\end{array}$ & $\begin{array}{c}2010 \\
0.0326 \\
2.900\end{array}$ & $\begin{array}{c}0.0293 \\
1.648\end{array}$ & $\begin{array}{c}10 \\
0.3369 \\
5.741\end{array}$ & $\begin{array}{c}010 \\
0.0378 \\
1.332\end{array}$ & & 5 & 4 & & $\%$ \\
\hline 1 & $\mathrm{Pifi}_{2013}$ & $\mathrm{C}$ & TMLEC & $\mathrm{TCAC}_{2010}$ & $\mathrm{TPNPC}_{20}$ & & 0.8059 & 46.65 & 3 & $5 \%$ & 1 \\
\hline 2 & $\mathrm{t}$ & $\begin{array}{c}-0.0217 \\
-3.254\end{array}$ & $\begin{array}{c}2010 \\
0.0466 \\
5.893\end{array}$ & $\begin{array}{c}0.2541 \\
6.177\end{array}$ & $\begin{array}{c}10 \\
0.0248 \\
2.018\end{array}$ & & & 8 & 4 & & $\%$ \\
\hline
\end{tabular}

Source: of our own making with information from the SEP (2006a, 2006b, 2014), UNAM (2014) and Rubio (2006). 
In general they show a high statistical significance, and they have an acceptable adjustment flexibility that ranges from 43.4 to nearly 86 per cent. This contributes overall evidence that the SEP has efficiently used the special resources to promote the strengthening of the competitiveness and academic capabilities indicators of the UPES, with the purpose of improving the quality of higher education in México.

In second place, the econometric analysis also shows a differentiated behavior by the federal authority. For example, between 2002 and 2003, the quality of the bachellor programs offered by the UPES determined in an important way the levels of allocations that these received. This can be verified upon observing their individual statistical significance in relation to the other variables of equations 1 and 2. For the years 2002, 2004 and 2005, the progress of the IES's in strengthening their teaching staff's with more Ph.D. in their PTC, with SNI and PROMEP profile, were rewarded through the subsidies.

For the period that runs from 2004 to 2013 at least two behavior patterns can be observed. In the first place, a sustained phase of the bidding funds distribution linked to progress in the field of education equity, growth of enrollment in the quality programs, and the strengthening of the universities' consolidated academic bodies (CAC). Even though between 2002 and 2005 the CAC's had a moderate impact due to a lack of significance in their statistical $t$, as from 2006 its relevance becomes stronger as a determinant factor in the distribution. According to the SEP (2006a), this was due to that until the year 2001, team work at the universities was carried out around the educational programs and very seldom considering the common research interests, so SEP implemented integration work-shops of academic work-groups to plan and develop the CA's in the PIFI's, emphasyzing that the main area for a CA should be the innovative generation and application of knowledge.

Between 2007 and 2013 a second phase is identified where beside educational equity and the strengthening of the CA's, the quality of graduate programs becomes relevant in the distribution of extraordinary funds. Equations 6 and 12 include the progress of the UPES's in this concept with more robust results in terms of its statistical significance and power of adjustment, which are coherent with the policy implemented by the federal authority starting from 2008. This allowed the linkage of the PIFI with the PNPC of CONACYT in its two aspects: the Quality Promotion Program (PFC) and the National Graduates Registry (PNP), through assistance that have a direct impact upon the improvement processes of the graduate programs of the UPES's. 


\section{Final Remarks}

The results of this study confirm that public policies of extraordinary public financing towards the UPES's during the analyzed period, have generated significant positive impacts upon the processes of quality consolidation and a decrease of the institutional inequalities of the UPES's. This is because between 2002 and 2013, in general the PIFI has rewarded in a timely manner the progress shown by the UPES in the field of their institutional performance.

The quality of the educational programs of undergraduate and graduate levels that the UPES offer, as well as the advances in the field of educational equity in undergraduate programs were the indicators with greater relevance for the determination of the amounts distributed by the federal authority. In regards with the graduate programs, these results are consistent with the policy and the changes implemented by the SEP as from 2008, because until before this year the PIFI had only indirect impacts on the graduate educational level of the IES's. The public policy has been able to link the PIFI with the PNPC of CONACYT through supports with direct impact upon the improvement processes of these level of programs.

Regarding the incidence of the special funds for the generation of best institutional practices, it may be said that the progress achieved by the UPES is explained in good measure by the degree of subsides they obtained in a competitive manner between 2001 and 2013. That becomes clear when performance levels of the UPES are compared with the allocations received over the long term, because their most evident and robust progress has been attained in the sphere of quality and equity of the bachelors programs that they offer. At the end of the period, UPES have accredited the greater part of their bachellor programs and increase the opportunities to access it, assuming upon the premise that for an educational opportunity to allow social equity, it must be of an accredited quality.

\section{References}

Aguilar, H. y Castañeda, J. (2009). Un futuro para México. México: Punto de Lectura.

Asociación Nacional de Universidades e Instituciones de Educación Superior. (2002). Propuesta de lineamientos para una política de Estado en el financiamiento de la educación superior, México.

Arizmendi, R. y Mungaray, A. (1994). Relación entre la educación y el desarrollo económico de México. Comercio Exterior, 44 (3), 193-198.

Bruner, J.J. (Coord.). (1994). Educación superior en América Latina. Una agenda de problemas, políticas y debates en el umbral del año 2000. Buenos Aires, Argentina: CEDES. 
De Vries, W. (2002). Políticas federales en la educación superior mexicana. Alliance for International Higher Education Policy Studies. Recuperado de: http://www.nyu.edu/iesp/aiheps/research.html

Márquez, A. (1999). El costo familiar y/o individual de la educación superior. México: ANUIES.

Mungaray, A. and López, R. (1996). Introduction to Latin American Higher Education challenges and perspectives in the nineties. Higher Education Policy, 9 (1), 3-9.

Muñoz, C. (1988). La educación superior ante las políticas derivadas de la crisis. Revista de la Educación Superior, XVII (1) no. 65, enero-marzo, 5-14.

O'Leary, R. and Vij, N. (2012). Collaborative Public Management: Were Have We Been and Were Are We Going. American Review of Public Administration, 42 (5), 507-522.

Rodríguez, R. (1995). El financiamiento de la educación superior en México. Elementos para la discusión. Políticas de Financiamiento a la Educación Superior. En R. Cordera y D. Pantoja (Coords.), 75-82. México: CESU/M.A. Porrúa.

Rubio, J. (2006). La política educativa y la educación superior en México 1995-2006. Un balance. México: FCE.

Secretaría de Educación Pública. (2014). Datos de matrícula y de calidad de las Universidades Públicas Estatales (UPES) y de Apoyo Solidario (UPEAS). SES/DGESU. Recuperado http://www.dgesu.ses.sep.gob.mx/Principal/universidades/matriculaupes.aspx

Secretaría de Educación Pública. (2006a). Programa de Mejoramiento del Profesorado. Un primer análisis de su operación e impacto en el proceso de fortalecimiento académico de las Universidades Públicas. México: SEP. Recuperado de: http://dsa.sep.gob.mx/pdfs/Promep\%20Libro.pdf

Secretaría de Educación Pública. (2006b). Estudio de la eficiencia terminal de las IES mexicanas. Subsecretaría de Educación Superior. Recuperado de: http://www.ses.sep.gob.mx/wb/ses/estudio_de la eficiencia terminal de las ies

Sorensen, E. and Torfing, J. (2011). Enhancing Collaborative Innovation in the Public Sector. Administration \& Society, 43, 842-868.

Universidad Nacional Autónoma de México. (2014). EXECUM. Base de datos de indicadores institucionales de las Universidades Públicas Estatales. Recuperado de: http://www.execum.unam.mx/

Valenti, G. y Mungaray, A. (1997). Introducción. Políticas Públicas y Educación Superior. En Mungaray, A. and G. Valenti (Coords.), 7-21. México: ANUIES. 